\title{
DAMPAK PERUBAHAN JENIS DAN FUNGSI UANG BAGI PEREKONOMIAN MENURUT PERSPEKTIF EKONOMI ISLAM
}

\author{
Asra, S.Sy., M.Ag \\ Fakultas Ekonomi dan Bisnis Islam IAIN Lhokseumawe \\ Email: Asra.almardy1745@gmail.com
}

\begin{abstract}
The alteration in the type and function of money which continue to roll creates a lot of new dynamics that are considered both positive and negative. In fact, this shift is influenced by many causes and reasons, this also affects the global economic problems. And it must be acknowledged that the issue of the type of money is the most crucial thing at the moment and continues to be debated on how to find solutions to the problem of paper money, especially related to inflation from the value of money itself. This paper tries to look out this issue, specifically from the perspective of the value of money (paper), where the value created is only based on perceptions or assumptions, not the value intrinsically attached to the medium of exchange itself, so it is very vulnerable to inflation.
\end{abstract}

Keyword: Changes in The Type, Function, Money, Islamic Economic.

\begin{abstract}
Abstrak
Perubahan jenis dan fungsi uang yang terus bergulir menimbulkan banyak dinamika baru baik yang dianggap perubahan ke arah positif maupun ke arah negatif. Secara faktual pergeseran ini di pengaruhi oleh banyak sebab dan alasan hal ini juga berefek pada persoalan ekonomi secara global. Dan harus diakui persoalan jenis uang adalah hal yang paling krusial saat ini dan terus diperdebatkan bagaimana mencari solusi terhadap persoalan uang kertas khususnya terkait inflasi dari nilai uang itu sendiri. Makalah ini mencoba melihat persoalan ini secara spesifik dari perspektif nilai uang (kertas), dimana nilai yang tercipta hanya berdasarkan persepsi atau anggapan, bukan nilai yang melekat secara intrinsik pada alat tukat itu sendiri, sehingga sangat rentan terhadap inflasi.
\end{abstract}

Kata Kunci: Perubahan Jenis, Fungsi, Uang dan Ekonomi Islam. 


\section{PENDAHULUAN}

Kebutuhan manusia terhadap mata uang telah terjadi sejak manusia mengenal transaksi tukur-menukar dengan sistem barter. Pada saat itu, manusia hanya mengandalkan kebutuhan dan kebetulan sebagai motivasi bertransaksi. Mereka merasakan kesulitan saat keinginannya untuk melakukan barter tidak dibarengi dengan kebutuhan orang lain yang memiliki barang yang dinginkan sebagai objek barter. Alhasil, mereka harus menunggu kebutuhan atau keinginan kedua belah pihak untuk melakukan sistem barter ini.

Sejalan dengan perkembangan terknologi yang pesat, pola dan sistem pembayaran dalam transaksi ekonomi terus mengalami perubahan. Perubahan ini menggeser peranan uang tunai (currency) sebagai alat pembayaran sah menjadi pembayaran non tunai yang lebih efektif dan efesien. Di tambah lagi dengan keberadan berbagai pusat pembelanjaan yang memaksa konsumennya menggunakan kartu debit or kartu kredit dengan berbagai kemudahan dan diskon yang diberikan. Hal ini tentunya menjadikan uang kertas tidak lagi beredar di masyarakat tetapi yang beredar adalah uang giral. Sementara uang kertas hanya berada di perbankan dan perputaranya hanya pada pasar tradisional. Lalu timbul tanya besar "Apakah ini sebagai upaya penumpukan uang yang dilakukan oleh pihak perbankan?” sebagaimana dijelaskan oleh Takiddin (2014) bahwa efek dari penumpukan uang ialah memperlambat peredaran uang, memperkecil transaksi dan menjadikan perekonomian lesu.

Pembahasan makalah ini menggunakan metode Analisis literatur, yaitu metode dengan objek kajiannya berfokus pada artikel-artikel,jurnal dan buku-buku yang relevan dengan topik yang dibahas.sebagai pengayaan tulisan ini juga mencoba melihat secara faktual fenomena yang terjadi terkait jenis dan fungsi uang, sehingga imformasi yang kita peroleh seimbang dari segi teori dan fakta lapangan.

\section{Uang dalam Perspektif Ekonomi Konvensional}

\section{Pengertian Uang}

Uang sebagai media pembayaran telah dikenal sejak puluhan abad yang lalu. Secara sederhana uang dimaknai sebagai alat pembayaran yang diterima secara umum oleh masyarakat. Penjelasan lebih lanjut mengenai uang, berikut diuraikan pendapat beberapa pakar dibidangnya, diantaranya menurut Mandala,dkk (2004) uang adalah asety ang paling likuid diantara seluruh aset yang ada dalam perekonomian. Suatu aset dikatakan likuid bila sangat mudah ditukarkan dengan barang dan jasa lain, biaya transaksinya sangat kecil dan nilai nominalnya relatif stabil. Pengertian ini lebih menekankan pada sifat uang sebagai aset yang likuid atau dapat dibelanjakan ka- 
papun oleh pemiliknya. Lain halnya menurut Mankiwuang (2000) adalah persediaan aset yang bisa dengan segera digunakan untuk melakukan transaksi. Dia juga berpendapatan bahwa uang merupakan segala sesuatu yang dapat dipakai atau diterima untuk melakukan pembayaran baik barang, jasa maupun hutang uang mempunyai satu tujuan fundamental dalam sistem ekonomi, memudahkan pertukaran barang dan jasa, mempersingkat waktu dan usaha yang diperlukan untuk melakukan perdagangan. Sedangkan menurut FredericS.Mishkin (2008), uang memiliki arti khusus bagi ekonom. Para ekonom membuat perbedaa nantara uang dalam bentuk mata uang, rekening koran (tabungan) dan dalam bentuk lainnya yang digunakan untuk transaksi dan kekayaan. Dalam masyarakat, dianggap bahwa semakin kaya atau semakin makmur seseorang maka uang yang dimilikinya semakin banyak. Tetapi bagi ekonom, uang tidaklah menjadi bagian dari seluruh kekayaan tetapi salah satu bentuk dari kekayaan atau asset yang digunakan untuk proses transaksi. Masyarakat juga menganggap bahwa uang adalah pendapatan (income). Tetapi bagi seorang ekonom mendefenisikan uang (juga sering disebut sebagai uang beredar) sebagai sesuatu yang secara umum diterima dalam pembayaran barang dan jasa atau pembayaran atas utang berbeda dengan kekayaan dan pendapatan. Berdasarkan beberapa pendapat diatas, dapat disimpulkan bahwa uang adalah sesuatu yang dipercayai, diterima dan dianggap bernilai oleh masyarakat, digunakan untuk aktivitas perekonomian baik transaksi barang dan jasa, penyimpan kekayaan atau ukuran kekayaan.

\section{Jenis-jenis Uang}

Perkembangan teknologi ikut merubah jenis uang yang beredar dalam masyarakat. Salah satu faktor perubahan jenis tersebut ialah kompleksnya transaksi yang dilakukan oleh masyarakat. Sehingga kebutuhan alat pembayaran yang dapat digunakan secara efektif, tidak hanya transaksi tunai, non tunai bahkan transaksi jarak jauh. Uang yang dapat digunakan secara efektif ialah mata uang yang mempunyai standarisasi yang sederhana sehingga mudah menentukan harga, dapat diterima secara luas, mudah disalurkan, mudah dibawa ke berbagai tempat, dan tidak cepat terdepresiasi (Billah, 2010). Dan ini menjadi tuntutan bagi pemerintah atau lembaga terkait untuk memberikan fasilitas yang dapat mendorong efektivitas penggunaan uang. Hal ini telah membuat uang berevolusi sedemikian rupa dalam masyarakat. Hingga, saat ini telah terdapat lima jenis uang yang pernah dan sedang digunakan oleh masyarakat, yaitu:

\section{a. Full Money}

Full money dimaknai dengan uang yang memiliki nilai penuh yakni nilai materinya sama dengan nilai nominalnya atau dapat juga disebut dengan mata uang yang memiliki nilai intrinsik sama dengan nilai nominalnya. Jenis mata uang ini harus terpenuhi dua syarat yaitu:pertama, setiap individu yang memiliki mata uang ini 
berhak untuk menempah sendiri baik meleburnya, menjualnya atau memakainya. Kedua, setiap orang mempunyai hak yang tidak terbatas menyimpan uang ini. Saat ini jenis uang ini tidak lagi dapat dijumpai dalam perederannya karena dewasa inimayoritas negara cenderung menggunakan kertas sebagai satuan ukur dan media pembayaran (Ahmad Syah, 2004).

Full money dalam istilah modern lebih dikenal dengan uang komoditas (commodity money). Maksudnya ialah uang yang bisa berfungsi ganda yakni sebagai komoditas yang dapat diperjual belikan dan disisi lain komoditas ini juga dapat dijadikan alat ukur barang dan jasa. Namun, tidak sembarang komoditas yang dapat dikatagorikan sebagai uang jenis ini karena hanya komoditas yang langka, tahan lama dan mempunyai nilai tinggi yang dapat ditempah menjadi uang (Rianto, 2010). Dalam hal ini, komoditas yang sangat cocok ialah emas dan perak. Akan tetapi betapa pun sempurnanya jenis uang ini, tetap saja mempunyai kelemahan untuk menjadikan alat ukur dalam setiap transaksi terutama transaksi rumah tangga yang relatif tidak membutuhkan alat ukur bernilai tinggi, seperti pembelian kebutuhan sehari-hari.

b. Token Money

Token money yaitu jenis mata uang yang memiliki nilai intrinsik lebih kecil dari nominalnya. Jenis uang dalam katagori ini disebut juga dengan fiat money (uang hampa). Kelebihan jenis uang dalam bentuk ini ialah dapat diukur nilainya karena dibuat oleh lembaga khusus di bawah pemerintah, seperti Bank Sentral, Pemerintah dan bank-bank Deposito.

c. Floding Money

Floding money atau disebut juga dengan uang kertas. Umumnya negara-negara yang memilih mencetak uang ini disebabkan oleh tiga faktor, yaitu:

1) Biaya yang dikeluarkan untuk mencetak uang ini relatif kecil dibandingkan uang logam;

2) Uang kertas mudah dibawa atau disalurkan terutama bagi negara yang memiliki wilayah yang sangat luas;

3) Pemerintah dapat memenuhi kebutuhan mendesak kapapun dan dalam kondisi apapun disebabkan mudahnya bahan baku pembuatan uang jenis ini bila dibandingkan dengan logam atau emas yang sifatnya langka atau sulit untuk diperoleh (Israk, 2010).

Karena sifat uang kertas dijamin oleh negara atau lembaga tertentu, maka jenis uang dalam bentuk ini sering pula dinamakan dengan uang "kepercayaan." Dalam peredarannya, uang kertas dapat dibedakan menjadi dua jenis, pertama uang kertas pemerintah yakni uang yang dicetak oleh pemerintah dan dijamin dengan undang-un- 
dang atau peraturan tertentu. Kedua, uang kertas bank yakni uang kertas berbentuk surat hutang yang dapat diperjual belikan (Israk, 2010, hlm. 20), dan surat ini biasanya terdapat dalam pasar uang, seperti SBI, SWBI, SIMA dan bentuk lainnya.

d. Uang Giral

Uang giral ialah jenis uang yang dikeluarkan oleh perbankan untuk nasabah pemegang rekening giro. Jenis uang ini dapat berupa cek, bilyet giro atau sarana perintah lainnya. Kelebihan uang jenis ini adalah mudah dilacak pemakaiannya oleh perbankan, sehingga bila digunakan oleh orang yang tidak berhak, bank dalam hal ini dapat mengambil tindakan tegas dengan menolak pencairan warkat tersebut. selain itu jenis uang ini juga lebih mudah dialihkan ke pihak lain dengan biaya yang relatif murah serta memudahkan pembayaran atas transaksi tanpa harus menyertakan uang dalam jumlah yang banyak, namun cukup dengan sepotong kertas kecil (cek).

e. Near Money

Near money ialah jenis mata uang yang dapat dicairkan dalam waktu yang singkat, seperti Time Depositdan Obligasi Pemerintah (Israk, 2010). Time Deposit merupakan salah satu produk penghimpunan dana bank dalam bentuk rekening khusus yang dapat ditambah atau ditarik kapanpun, namun nasabah harus menyimpan sebagian dananya sebagai dana minimum dan imbalanya dibayar berdasarkan saldo harian. Sedangkan obligasi biasanya dikeluarkan oleh bank sentral sebagai instrumen pengendalian peredaran uang itu sendiri dalam rangka menjaga stabilitas nilai mata uang.

Perubahan jenis uang, seperti yang telah diuraikan di atas mempunyai efek positif bagi perekonomian, di sisi lain juga memiliki dampak negatif yang tidak dapat dihindari oleh otoritas pengambil kebijakan. Untuk pembahasan yang lebih jelas, penulis akan menganalisis lebih mendalam dalam poin pembahasan berikutnya.

\section{a. Fungsi Uang}

Secara umum fungsi uang dapat diklasifikasikan menjadi empat yaitu media pertukaran, satuan hitung, alat menyimpan nilai dan standar pembayaran tunda. Masing-masing fungsi tersebut dapat dirincikan sebagai berikut:

1. Uang sebagai media pertukaran(medium of exchange)

Uang merupakan alat tukar yang digunakan setiap individu untukmedia pertukaran komoditas dan jasa. Uang adalah segala sesuatu zat yang tidak ada harganya kecuali nilai itu sendiri dan dengan nilai tersebutlah bisa mendapatkan sesuatu yang dibutuhkan secara adil (Rivai, 2010). Hal ini senada dengan ucapan Imam Al-Ghozali yaitu uang seperti cermin yang tidak memiliki warna namun dapat memantulkan semua warna (Abdullah, 2010). Begitu juga uang, uang bukanlah 
harga, namun uang dapatmerefleksikan semua harga. Uang tidak diciptakan untuk seseorang saja, akan tetapi diciptakan untuk diedarkan agar mencari perantara (alat tukar) bagi manusia.

2. Uang sebagai Satuan Hitung (Unit of Account)

Uang adalah standar ukuran harga, yakni sebagai media pengukurnilai atau harga barang dan jasa. Selain itu uang juga mampu mengukur perbandingan harga setiap komoditasdengan komoditas lainnya.Melihat fungsi ini, uang merupakan suatu yang sangat dibutuhkan dalam perekonomian. Kebutuhan ini juga tersurat dalam firmanAllah SWT, yaitu:

Yang artinya: "Sesungguhnya Allah tidak Menganiaya seseorang walaupun sebesar zarrah, dan jika ada kebajikan sebesar zarrah, niscaya Allah akan melipat gandakannya dan memberikan dari sisi-Nya pahala yang besar."(QS. An-Nissaa' (4) : 40).

Ayat ini menjelaskan ukuran dalam satuan nilai. Dalam ayat di atasdisebut dengan kata sebesardzarahmaka ayat ini juga memberikan gambaranperlunya ukuran-ukuran dalam segala hal. Uang dalam fungsinya sebagaistandar ukuran umum harga berlaku untuk ukuran nilai dan harga dalamekonomi, seperti berlakunya standar meter untuk ukuran jarak, atauampere untuk mengukur tegangan listrik. Uang merupakan alat yang pastidiperlukan untuk setiap hitungan dalam ekonomi baik oleh produsenmaupun konsumen.

3. Uang sebagai Alat Penyimpan Nilai (Store of Value)

Uang merupakan salah satu pilihan untuk menyimpan kekayaan. Maksudnya adalah bahwa orang yang mendapatkan uang kadang-kadangtidak mengeluarkan seluruhnya dalam satu waktu, tapi disisihkan sebagianuntuk membeli barang atau jasa yang dibutuhkan pada waktu yangdiinginkan atau uang yang disimpan digunakan untuk hal-hal tak terdugaseperti sakit atau menghadapi kerugian yang tak terduga. Menyimpan uang tidak sama dengan menimbun uang. Menimbunuang menyebabkan terhentinya fungsi uang sebagaiflow concept Karim, 2008, hlm. 88). Menabung uang, dibolehkan dalam Islam tetapi harus di diputar jugadalam investasi. Uang yang disimpan kemudian tidak dialirkan pada sektor riil, sama dengan menimbun uang.

4. Uang sebagai standar pembayaran tunda(Standard of Deffered Payment)

Transaksi jual beli tidak selamanya dijalankan secara kontan, namun sering juga menggunakan sistem pembayaran angsuran. Hal inilah yang mengubah fungsi uang dari media pembayaran menjadi standar pembayaran tunda. Fungsi uang ini terkait dengan transaksi pinjam-meminjam, di mana uang dijadikan standar untuk menghitung jumlahpembayaran pinjaman tersebut. Dalam pandangan non Islam, 
uangyang dipinjamkan seringkali ditambah dengan sistem bunga saatpembayaran hutang. Hal inilah yang dimanfaatkan untuk mendapatkeuntungan dengan cara pembayaran tundadan sistem bunga tersebut dilarang oleh Islam.

Setelah dijelaskan berbagai fungsi uang pada paragraf di atas penulismenyimpulkan bahwa fungsi uang secara umum mencangkup empat fungsi. Tetapi Islam hanya mengakui dua fungsi saja yang melekat pada uang yakni uang sebagai media pertukarandan uang sebagai standar ukuran harga dan unit hitungan. Karena kedua fungsiini sesuai dengan kriteria hukum Islam. Penjelasan lebih mendalam tentang keunggulan fungsi ini dan efeknya bagi perekonomian akan diuraikan dalam poin pembahasan di bawah ini.

\section{HASIL DAN PEMBAHASAN}

\section{Dampak Perubahan Jenis dan Fungsi Uang Menurut Ekonomi Islam}

Islam memandang uang tidak lebih dari alat tukar dan alat ukur atas suatu komoditi atau produk jasa, di mana nilai uang tersebut hanya ada bila dibelanjakan. Sebagaimana disampaikan oleh Imam Malik bahwa uang adalah adalah alat tukar yang tidak memiliki nilai apabila tidak dibelanjakan. Dengan kata lain, uang tidak bisa menghasilkan keuntungan secara langsung, tetapi manfaatnya baru bisa dinikmati setelah dibelanjakan atau disalurkan ke kegiatan produktif. Hal yang senada juga disampaikan oleh Abu Ubaid (Karim. 2006), di mana ia menyebutkan bahwa "Hal yang tidak diragukan lagi bahwa emas dan perak tidak layak untuk apapun, kecuali keduanya menjadi harga dari barang dan jasa. Keuntungan yang paling tinggi yang dapat diperoleh dari kedua benda tersebut adalah penggunaanya untuk membeli sesuatu"( Abdullah, 2014). Implikasi dari pendapatnya tersebut adalah uang hanya berfungsi sebagai alat tukar dan alat ukur dan uang tidak bisa menjadi objek perdagangan, karena jika uang dijadikan komoditas maka harga akan mengalami berfluktuasi sebagaimana barang lainnya (Abdullah, 2014). Dengan demikian, uang akan mudah terdepriasi sehingga uang sebagai media yang memiliki standar nilai yang relatif tetap tidak lagi dapat dipertahankan, dampaknya stabilitas ekonomi akan terganggu.

Lebih jauh lagi, Al-Ghazali (dalam Karim, 2006) memiliki pandangan yang komprehensif terhadap uang, diantaranya ia menegaskan bahwa evolusi uang terjadi karena kesepakatan dan kebiasaan, yakni tidak ada masyarakat tanpa pertukuran barang dan tidak ada pertukaran yang efektif tanpa ekuivalensi, serta ekuivalensi hanya dapat ditentukan apabila ada ukuran yang sama (Karim, 2006). Dalam hal ini ada alat ukur yang diterima secara umum oleh masyarakat dimaksudkan dengan uang. Mengenai fungsi uang, Al-Ghazali menyebutkan bahwa uang berfungsi sebagai:

1. Memperlancar pertukaran dan menetapkan nilai yang wajar dalam pertukaran 
tersebut;

2. Uang sebagai alat penengah antara kepentingan pembeli dengan penjual.

Tidak hanya itu, pendapatnya tentang evolusi dan fungsi uang, Al-Ghazali memiliki pandangan yang sangat luas tentang dapat yang ditimbulkan dari penimbunan uang, peredaran uang palsu, dan jual beli uang. Menurutnya, menimbun uang berdampak pada berkurangnya peredaran uang dalam masyarakat, sehingga uang yang seharusnya dinikmati oleh masyarakat luas, kini menjadi milik sebagian kecil orang. Akibatnya ialah produktivitas usaha menurun disebabkan penurunan permintaan terhadap barang karena berkurang uang dalam masyakarat. Sehingga para produsen kesulitan mengembangkan usaha dikarenakan keuntungan menurun (Karim, 2006). Akhirnya harga-harga barang naik, dalam hal ini inflasi menjadi permasalahan baru yang menggangu stabilitas nilai tukar uang. Dampak jangka panjangnya perekomian akan lesu, kemiskinan meningkat, kesenjangan ekonomi semakin terlihat, pengangguran meningkat serta pertumbuhan ekonomi semakin sulit diwujudkan oleh pemerintah.

Inilah efek dari penimbunan uang atau dengan kata lain memberhentikan beredarnya uang dalam masyarakat. Oleh sebab itulah, Adiwarman menegaskan bahwa semestinya uang itu milik semua masyarakat (public goods), bukan milik sebagian kecil dari masyarakat (private good) (Karim, 2008). Karena bila uang dinikmati sebagian orang, maka dampak di atas merupakan akhir dari kondisi perekonomian. Dalam hal ini Adiwarwan juga membedakan antara uang dengan modal. Uang bersifat flow concept, sedangkan modal bersifat stock concept. Maksud dari pembedaan ini ialah Adiwarman mengambarkan secara lugas mengenai dampak negatif dari pelaksanaan fungsi uang sebagai alat menyimpan nilai. Artinya uang yang disimpan akan mengendap dalam kepemilikan seseorang (stock concept), sehingga uang tersebut menjadi milik pribadi (private good) (Karim, 2008).

Selanjutnya, pandangan Al-Ghazali mengenai peredaran uang palsu. Menurut beliau peredaran uang palsu akan menambah jumlah uang yang beredar dalam masyarakat (Abdullah, 2014). Hal ini akan memicu inflasi karena semakin banyak uang yang tersedia untuk dibelanjakan akan mendorong masyarakat untuk berkonsumsi, disisi lain produsen akan menaikkan harga barang.

Adapun dampak dari jual beli uang ialah menurunkan minat bekerja karena mereka dapat memperoleh keuntungan dengan berspekulasi dalam hal jual beli uang. Akibatnya produktivitas sektor riil semakin menurut akibat kurang pekerja serta sulitnya mendapatkan modal (Abdullah, 2014). Dampak signifikan dari penurunan produktivitas tersebut, barang-barang menjadi langka dan harganya akan melambung tinggi. Dan bila kondisi ini terus berlanjut, permasalahan inflasi akan sulit ditekan oleh 
bank sentral karena transaksi dinominasi oleh transaksi semu, di mana permintaan uang meningkat tetapi tidak diiringi dengan peningkatan produktivitas.

Selain pendapat dari Imam Maliki, Abu Ubaid dan Al-Ghazali di atas, tokoh ekonomi Islam yang memiliki andil yang besar terhadap pengembangan ekonomi Islam modern ialah Ibnu Taimiyah (dalam Azwar, 2006) dan Ibnu Khaldun (dalam Azwar, 2006). Keduanya memiliki pandangan yang hampir sama tentang keberadaan uang dalam suatu perekonomian. Dalam hal ini, Ibnu Taimiyah berpendapat bahwa uang berfungsi sebagai pengukur nilai dan media pertukaran bagi sejumlah barang yang berbeda (Azwar, 2006). Lebih lanjut Ibnu Taimiyah mengatakan "Atsman (harga atau yang dibayarkan sebagai harga yaitu uang), dimaksudkan sebagai pengukur nilai barang-barang yang dengannya jumlah nilai barang-barang dapat diketahu; dan uang tidak pernah dimaksudkan untuk diri mereka sendiri." (Azwar, 2006). Maksud dari ucapannya tersebut ialah Ibnu Taimiyah hendak menegaskan bahwa segala bentuk perdagangan uang merupakan kegiatan yang dapat mengalihkan dari tujuan sebenarnya uang yakni alat ukur memperlancar transaksi. Adapun bagi pihak yang ingin menukar uang dengan uang lainnya, dalam Islam hal itu dibolehkan asalkan dilaksanakan secara tunai (Azwar, 2006). Adapun sustansi keberadaan uang dalam suatu negara ditegaskan oleh Ibnu Khaldun bahwa kekayaan suatu negara bukan ditentukan oleh banyaknya uang yang dicetak oleh negara tersebut, namun faktor yang sangat menentukan ialah produktivitas dari negara tersebut serta neraca pembayaran yang positif (Karim, 2001). Dalam hal ini Ibnu Khaldun telah memberikan gambaran bahwa negara yang baik adalah negara yang mampu menyeimbangkan antara sektor riil dengan sektor finansial dan antara kebijakan fiskal dengan kebijakan monoter. Dalam hal ini, uang baru dianggap berkualitas bila mampun mendorong sektor riil bekerja. Hasil dari pertumbuhan sektor riil ialah produk-produk dalam negeri menikat dan dimungkinkan untuk diekspor karena telah melebihi kebutuhan dalam negeri, hingga akhirnya neraca pembayaran suatu negara menjadi positif disebabkan ekspor lebih tinggi dari impor.

Berdasarkan pandangan-pandangan para ilmuan muslim di atas, maka tidak ada satu orang pun yang menyebutkan bahwa fungsi uang sebagai penyimpan nilai dan standar pembayaran tunda sebagaimana dibenarkan dalam ekonomi konvensional. Kedua fungsi tersebut mendorong pemegang uang untuk penimbunan uang dan spekulasi terhadap uang. Dampak jangka pendeknya ialah inflasi dan jangka panjangnya kondisi perekonomian akan depresi. Hal ini disebabkan uang memiliki hubungan yang erat dengan kegiatan ekonomi yang lain dan memiliki keterkaitan antara keduanya. Sebab, kekuatan uang bersandar pada kekuatan ekonomi dan ekonomi yang kuat ditentukan oleh uang yang pula (Al-Haritsi, 2006).

Pemaparan di atas telah menguraikan secara komprehensi tentang perubahan 
fungsi uang sebagai alat tukar menjadi objek yang dipertukarkan (diperjual belikan). Efeknya transaksi itu telah menimbulkan dampak negetif bagi perekonomian. Tetapi berbeda halnya dengan perubahan jenis uang, di mana perubahan jenis uang cenderung memunculkan efek positif bagi perekonomian. Hal ini didasarkan pada hasil penelitian Bank Indonesia yaitu munculnya berbagai alternatif alat pembayaran non tunai seperti Kartu Debit, Kartu Kredit, Bilyet Giro, dan lain sebagainya ternyata mampu memberikan dampak positif bagi kesejahteraan masyarakat. Hal ini dimungkinkan bahwa peredaran uang dalam masyarakat terjadi semakin cepat karena alat tersebut memudahkan mereka dalam melakukan proses transaksi seperti penarikan tunai, transfer dan pembayaran berbagai tagihan dengan biaya relatif lebih murah. Sehingga efektivitas dan efesiensi peredaran uang dalam masyarakat semakin meningkat dan ini dapat pertumbuhan mendorong sektor rill yang pada gilirannya akan diikuti oleh pertumbuhan ekonomi dan meningkatkan kesejahteraan masyarakat.

Berdasarkan pemaparan di atas, maka dampak perubahan fungsi uang dan jenis uang terhadap perekonomian dapat digambarkan sebagai berikut:

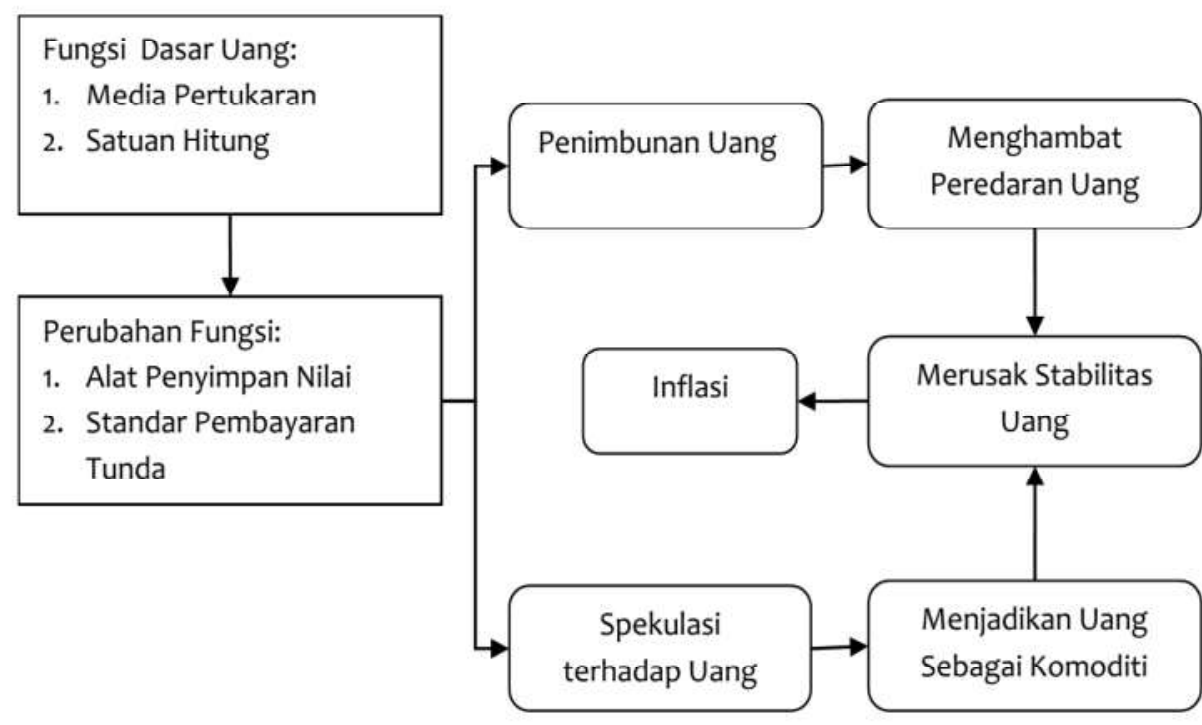

Gambar 1.1

Dampak Perubahan Fungsi Uang bagi Perekonomian

Gambar 1.1 di atas mengilustrasikan sederetan efek yang akan terjadi pada suatu perekonomian mulai dari fungsi uang pada awalnya hanya sebagai alat ukur dan pertukaran barang atau jasa, hingga peradaban mengubahnya menjadi alat penyimpan nilai dan standar pembayaran tunda. Perubahan fungsi ini yang memberikan efek negatif bagi perekonomian. Sebab Jika melihat dari realitas Indonesia, keberadaan uang giral menunjukkan hal sebaliknya yakni peredaran uang menjadi lebih cepat dari sebelumnnya. (data) dengan kata lain, uang semakin cepat berpindah nilainya ke rek- 
ening lain, walaupun bukan uang itu sendiri secara riil yang mengalami permindahan.

Adapun dampak dari adanya perubahan jenis uang dalam artian adanya alat transaksi lebih variatif ialah sebagai berikut:

\section{SIMPULAN}

Uang merupakan instrumen keuangan untuk digunakan dalam bertransik dalam rangka memudahkan mengukur dan menilai barang atau jasa yang dibutuhkan oleh masyarakat. Pada prinsipnya fungsi uang hanya untuk alat tukar dan alat ukur barang dan jasa. Namun dalam perkembangannya uang dijadikan pula alat penyimpan nilai dan standar pembayaran tunda. Dalam Islam kedua fungsi tambahan tersebut tidak diakui karena menimbulkan dampak negatif yang cukup besar dalam perekonomian. Meskipun Islam tidak melarang menabung tetapi setiap tabungan yang telah mencapai nisab akan dikenakan zakat. Dan bila tabungan itu terus diam tanpa disalurkan pada kegiatan yang produktif maka akan terkuras oleh zakat. Hal ini mengindikasikan bahwa Islam lebih menyukai memanfaatkan simpanan tersebut dari pada membiarkan mengganggur. Oleh sebab itulah timbul istilah, uang itu publik goods yakni hanya dengan melakukan transaksi ia bernilai dan bermanfaat bagi diri sendiri dan orang lain. Uang tidak bisa diambil manfaat dari uang itu sendiri, dalam ekonomi konvensional memanfaatkan uang dengan sistem bunga. Hal itu dilarang dalam Islam karena bunga bagian dari riba dan dampak membungakan uang ialah mengganggu stabilitas nilai mata uang itu sendiri. Dengan demikian seharusnya uang itu bersifat flow concept dan semakin cepat beredar dalam masyarakah, maka semakin cepat pula pertumbuhan ekonomi dalam diraih. 


\section{PUSTAKA ACUAN}

Al-Haritsi, J.B.A. (2006), Fiqih Ekonomi Umar bin Khatab, Asmuni Solihan Zamakhsyari (terj.), Cet. I, Jakarta: Khalifa.

Billah, M.M. (2010), Dinar Emas: Mata Uang Islam, Yusuf Hidayat (terj.), Malaysia: Sweet \& Maxwell Asia.

Boedi, A. (2010), Peradaban Pemikiran Ekonomi Islam, Cet. I, Bandung: Pustaka Setia.

Karim, A. A. (2001), Ekonomi Islam Suatu Kajian Kontemporer, Cet. I,Jakarta: Gema Insani Press.

Karim, A.A. (2006), Sejarah Pemikiran Ekonomi Islam, Cet. II, Edisi III, Jakarta: RajaGrafindo Persada.

Karim, A. A. (2008), Ekonomi Makro Islami, Cet.II, Edisi. II, Jakarta: RajaGrafindo.

Mankiw, N. G. (2000), Teori Makro Ekonomi, Terjemahan, Edisi V, Jakarta: Erlangga.

Rianto, M.N. (2010), Teori Makro Ekonomi Islam: Konsep, Teori dan Analisis, Cet. I, Bandung: Alfabeta.

Rivai, V., Firmansyah, R., Veithzal, A.P., \& Rizqullah, (2010), Islamic Financial Management, Cet. I, Bogor: Ghalia Indonesia.

Solikin \& Soseno, Uang: Pengertian, Penciptaan, dan Peranannya dalam Perekonomian, Publikasi Bank Indonesia pada Desember 2002, http://www.bi.go.id/id/ publikasi/seri-kebanksentralan/Documents/1.\%20Uang.pdf, diakses 13 November 2016.

Sukirno, S. (2012), Makro Ekonomi Teori Pengantar, Cet. XXI, Edisi Ketiga, Jakarta: Rajawali Pers.

Syah, I.A (2004), Mata Uang dalam Islam, Banda Aceh Ar-Raniry Press. 